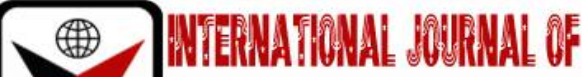

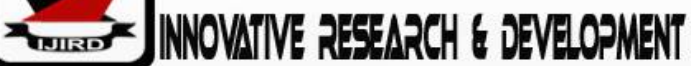

ISSN 2278 - 0211 (Online)

\section{Determinants of Farmers' Behavior in Utilizing Straw as Organic Fertilizer in Their Rice Field in Subang Regency, Indonesia}

Lies Sulistyowati
Handoko
Lecturer, Department of Agricultural Economics, Padjadjaran University, Indonesia
Master Student, Department of Agricultural Economics, Karawang Regency, Indonesia
Maman H Karmana
Trisna Insan Noor
Aecturer, Department of Agricultural Economics, Padjadjaran University, Indonesia
Adi Nugroho
Lecturer, Department of Agricultural Economics, Padjadjaran University, Indonesia
Lecturer, Department of Agricultural Economics, Padjadjaran University, Indonesia

\begin{abstract}
:
Green revolution has succeeded in increasing Indonesia's rice production, but it also has an impact on decreasing the level of soil fertility, due to the excessive use of chemical fertilizers. Subang Regency is one of the rice production centers in West Java, where some farmers have begun to utilize straw as organic fertilizer as an effort to improve soil fertility, as well as the sustainability of their farming. This study aims to compare the production, farmers' income, and R-C ratio of farmers who use straw compared to those who do not use straw as organic fertilizer, as well as analyzing the factors that influence farmers to utilize straw. The study uses quantitative inquiry, sample was taken by using multi stage cluster sampling. Research was conducted on 228 respondents in Binong, Pusakanegara, and Patokbeusi Sub-District, Subang, West Java. Data were collected through semi-structured interviews. Data were analyzed with descriptive analysis and logistic regression function. The results showed that the level of production, income, and R-C ratio of farmers who return straw is higher than the farmers who do not return. Aside of that, factors that influence farmers' decision to return straw to rice fields are income level and nature of innovation.
\end{abstract}

Keywords: Rice straw, logistic regression, factors, income

\section{Introduction}

\subsection{Research Background}

Rice has been known as Indonesians main staple food that is still hard to replace, thus, making the increasing demand hard to control. In line with Malthusian theory, this condition poses serious threat for future food security combined with the increasing population. Indonesia's population has increased from 237,556,363 in 2010 to 259,600,893 in 2016 with the annual rate of 1.49\% (Kementrian Pertanian, 2017). Rice price in the national level is controlled by the government to make sure that every citizen, especially those with low-mid income level has access to food. This policy is of course helpful for the consumers, but not so helpful for the producers, especially farmers. Low price of rice will reduce the incentives received by the farmers, which will then reduce their motivation to farm and increase the chance of them to work in other sectors.

Subang Regency is the third largest rice producer in West Java, following Indramayu and Karawang Regencies. In 2015 the paddy field area of Subang covered 41.22\% of its total land, producing 1,153,807 tonnes of rice as shown on Table 1 below. 


\begin{tabular}{|c|c|c|c|c|c|}
\hline \multirow{2}{*}{ Item } & \multicolumn{4}{|c|}{ Year } \\
\cline { 2 - 6 } & 2011 & 2012 & 2013 & 2014 & 2015 \\
\hline $\begin{array}{c}\text { Production } \\
\text { (Ton) }\end{array}$ & 1.180 .594 & 1.149 .147 & 1.204 .829 & 1.147 .650 & 1.153 .807 \\
\hline$\Delta$ Production (Ton) & & -31.447 & 55.682 & -57.179 & 6.157 \\
\hline$\Delta$ Production (\%) & & 2,66 & 4,85 & 4,75 & 0,54 \\
\hline Productivity (Qu/Ha) & 66,12 & 67,16 & 67,86 & 64,99 & 70,44 \\
\hline$\Delta$ Productivity (Qu/Ha) & & 1,04 & 0,7 & $-2,87$ & 5,45 \\
\hline$\Delta$ Productivity (\%) & & 1,57 & 0,01 & 4,23 & 8,39 \\
\hline
\end{tabular}

Table 1. Dryland and Wetland Paddy Production (Ton) and Productivity (Qu/ Ha) in Subang

Regency, Indonesia, 2011 - 2015

Source: BPS Kabupaten Subang, 2016

The growth of Subang's rice production and productivity fluctuated with the tendency of going stagnant. This shows that the marginal productivity of rice filed almost reaches its levelling off point. However, there are some ways in tackling this situation; some of those are intensification and technological advancement. These efforts are more feasible to increase production in this condition compared to intensification. The other alternative would be to increase productivity through increasing efficiency. Farming efficiency can be in form of many activities, such as reusing the waste (grain) as agricultural input (fertilizer) as a way to reduce the cost.

Land degradation is one of the many factors hampering Indonesia's rice production. The continuous application of chemical agricultural inputs overdose has reduced the soil porosity, increasing its solidity and degrading its quality. Soil solidification also leads to root growth restrictions and limiting oxygen and other nutrition mobility in the soil, which reduce plant productivity (Safitri, 2010). Straw as the waste of paddy production can be used as organic fertilizer, which has the potential to repair the soil and maintain its nutrition balance. In Indonesia, most farmers are not recycling straw as fertilizer in their rice field; they prefer to burn it (Amrah, 2008).

Straw recycle is one of Indonesian local wisdoms that are nearly forgotten. This activity can give a lot of advantages such as increasing the soil's organic materials which can maintain and increase its fertility also; it's a form of cost reduction since farmers don't have to buy organic fertilizer. Organic matters play an important role in maintaining soil condition by increasing microorganism function in the soil so that it will increase fertilizers' effectivity and the plants' productivity. Arafah and M. Sirappa (2002) stated that the use of straw to the rice filed can increase the number of microorganism and increasing the mass of the yield. This statement is also supported by Arya Sudiadnyana (2012), who stated that paddy production increase through the application of straw is caused by: 1) Increasing N (Nitrogen) supply, 2) more stable N release, 3) increasing K (potassium) supply, 4) increasing other nutrition supply, 5) soil structure repairing. However, most of Indonesian farmers have not practice this yet, thus, the research would like to identify the factors that influence the farmers decision in this matter.

\subsection{Problem Statement}

Based on the phenomenon, this research will try to answer these questions:

- How is the income of farmers who reuse their straw compared to those who do not?

- What are the determining factors for farmers to recycle their straw?

\section{Literature Review}

High paddy production in Subang regency is in line with high number of straw productions as its waste. In general, the straw production is 1.4 times paddy production (Kim and Dale 2004 in Isroi 2009). The average production of Binong and Patok Beusi Districts is $94.7 \mathrm{qu} /$ ha and $73.67 \mathrm{qu} / \mathrm{ha}$, this has the potential to produce more than 100,000 tonnes of straw per harvest season. This potential is, however, still not utilized especially in repairing and maintaining soil quality. As in other areas in Indonesia, the farmers in these two areas are still disposing the waste by burning it. The potential of very large harvested rice straw should not be burned, but used as compost fertilizer, so nutrients can meet half of the needs of chemical fertilizers. Straw returns are one of the local wisdoms that provide benefits to increase soil organic matter content. In addition, the addition of organic straw material can reduce the use of inorganic fertilizers. Organic matter is needed to maintain soil fertility by maintaining and improving the function of microorganisms in the soil to increase the availability of nutrients in the soil also increase the effectiveness of fertilization. With abundant amounts at harvest, the return of straw to the soil is a good way to improve nutrient balance so that the preservation of fertility of rice fields can be maintained for sustainable agriculture.

In optimal utilization of rice straw utilization into rice fields by farmers in Subang Regency is caused by several factors, both internal factors of farmers and external factors. Factors influencing farmers' decision making in returning straw to rice fields include 1). Internal factors are age, education, farming area, and income level; and 2) External factors: economic environment, social environment and nature of innovation. The speed of technology adoption is influenced by various factors including technological characteristics (economic and social benefits, compatibility/suitability, complexity/ level of difficulty and observability); characteristics of the social environment (pattern of decision making, existence of information sources, tolerance for change); personal characteristics of farmers (age, education, social status, main occupation) and the characteristics of the farm (plantation area, age of plants, clones, slope of land and number of trees / ha) (Herman et al., 2006). Whereas according to Rogers (2003) the speed of innovation diffusion, besides being 
influenced by individual characteristics, also influenced the characteristics of innovation, namely relative advantage, compatibility, complexity, trialability, and observability. Furthermore, the results of a study from Launio, et al., (2013) found that: On the determinants of rice straw management practice or why farmers choose to burn, incorporate, or remove rice straw, a mix of socio-economic, farm, and awareness and attitude variables are prominent.

In farming, the allocation of the use of production factors plays an important role because of the inappropriate use of the number and combination of factors of production resulting in low production produced or high production costs (Doll and Orazem, 1984). Low production and high production costs indicate that farming is not efficient. The return of straw can increase the production of broad unity. This can be explained because straw contains complete nutrients in the form of both macro and micro nutrients. In general, N, P, K nutrients are $0.4 \%, 0.2 \%$ and $0.7 \%$, respectively, while $\mathrm{Si}$ and C content are quite high at 7.9\% and 40\% (Tanaka in Team Balitpa, 2001). The research results of the Indonesian Plantation Biotechnology Research Institute (BPBPI) in Nugroho (2011), the content of straw compost is: C/ N ratio of 18.88; Corganic 35.11\%; Nitrogen 1.86\%; P2O5 0.21\%; K2O 5.35\%; and water content of 55\%. From the BPBPI analysis data, straw compost containing nutrients is equivalent to $41.3 \mathrm{~kg}$ of Urea; $5.8 \mathrm{~kg} \mathrm{SP36;} \mathrm{and} 89.17 \mathrm{~kg}$ KCL per ton of compost straw or a total of $136.27 \mathrm{~kg}$ of NPK per ton of compost (Rosinta, 2013).

\section{Methodology}

The research design uses quantitative descriptive. Descriptive research studies problems, procedures that apply, certain situations, including relationships, activities, attitudes, views, and processes that are taking place in the community as an influence of a phenomenon. Quantitative research is a research conducted to raise facts, variables, or phenomena which are then displayed as they are at present (Sugiyono, 2012). The data used are primary data and secondary data. Primary data was collected from 228 rice farmers in Binong Subdistrict, Patokbeusi and Pusaka Nagara District, Subang Regency which were collected in a multistage cluster sampling.

The analytical method used in this study uses quantitative descriptive. To answer the first problem is done using descriptive, the second problem is using logistic regression data analysis. The model is formulated as follows (Pindyck and Rubinfeld, 1998):

$P_{i}=\frac{1}{1+e^{-Z_{i}}}$

Where:

$Z_{i}=\beta_{0}+\sum_{j=1}^{n} \beta_{j} X_{j i}$

details:

$P_{i} \quad=$ Chance of individual to make decision

$\beta_{0} \quad=$ Intercept

$\beta_{j} \quad=$ Regression coefficient

$X_{j} \quad$ = Independent variables

Both formulas (1) are multiplied with $1+e^{-Z_{i}}$ to get:

$\left(1+e^{-Z_{i}}\right) P_{i}=1$

By simplifying formula (3) we get this formula:

$e^{Z_{i}}=\frac{P_{i}}{\left(1-P_{i}\right)}$

Transforming two formulas in (4) to a natural logarithm model based on formula (2) will generate this formula:

$Z_{i}=\ln \left(\frac{P_{i}}{1-P_{i}}\right)=\beta_{0}+\sum_{j=1}^{n} \beta_{j} X_{j i}$

Formula (5) is also known as logit model or logistic regression model.

Based on the factors that are thought to influence it, the logit model can be described as follows:

$\ln \left(\frac{P_{i}}{1-P_{i}}\right)=Z_{i}=Y_{i}=\beta_{0}+\sum_{j=1}^{n} \beta_{j} X_{j i}$

Details:

$P_{i} \quad$ : The chance of farmers willing to recycle straw

$1-P_{i} \quad$ : The chance of farmers not willing to recycle straw

$Z_{i} \quad$ : Farmers' decision

$Y_{i} \quad:$ Farmers return straws to rice field $\left(Y_{i}=1\right)$

Farmers do not return straws to rice field $\left(Y_{i}=0\right)$

$\beta_{0} \quad$ : Intercept

$X_{j} \quad$ : Determining factors $(j=1, \ldots, 7)$

$X_{1} \quad$ : Age

$X_{2} \quad$ : Education

$X_{3} \quad$ : Farm scale

$X_{4} \quad$ : Income

$X_{5} \quad$ : Economic environment

$X_{6} \quad$ : Social environment 
$X_{7} \quad$ : Innovativeness

$\beta_{j} \quad$ : Regression coefficient $(j=1, \ldots, 7)$

\section{Results and Discussion}

\subsection{Farm Income Comparison between Farmer Returning Straw and Not Returning Straw}

The comparison of rice farming between returning straw and those that do not return can be viewed from two aspects, namely the use of production inputs and cultivation techniques. The cultivation techniques between those who return straw to rice fields with those that do not return are not much different. The more prominent of the two straw treatments can be seen from the use of inorganic fertilizers and handling of post-harvest straw. In rice cultivation that returns straw to rice fields, straw is left to rot for 2 months or compost for 2 weeks before being returned to rice fields, while in rice cultivation that does not return straw is burned or transported outside the rice fields for mushroom cultivation or animal feed (UPTD Agriculture District Binong and Patok Beusi, 2017). There are ongoing processes and stages in rice cultivation by returning straw to the rice fields; it takes time to improve soil fertility and ecosystem balance. Improvement of soil fertility can be done in stages, farmers who do not return straw to paddy fields do not immediately return straw to the wetlands, and an ongoing approach and assistance is needed so that farmers are motivated.

Based on the results of the farm analysis in Table 4, it shows that the average income of rice farmers who return straw to the rice fields (Rp.19,716,997 per season per hectare) is greater than that of farmers who do not return straw (Rp.18,167,059 per season per hectare). The results of different tests are presented in Table 2.

\begin{tabular}{|c|c|c|c|c|}
\hline Variables & T Value & $\begin{array}{c}\text { Degree of } \\
\text { Freedom }\end{array}$ & $\begin{array}{c}\text { Sig. } \\
\text { (2-Tailed) }\end{array}$ & Status \\
\hline Production $(\mathrm{Kg} / \mathrm{Ha})$ & 1,993 & 226 & 0,047 & Significant \\
\hline Revenue $(\mathrm{Rp} / \mathrm{Ha})$ & 1,649 & 226 & 0,101 & Non-significant \\
\hline Seed cost $(\mathrm{Rp} / \mathrm{Ha})$ & $-0,245$ & 226 & 0,806 & Non-significant \\
\hline Fertilizer cost $(\mathrm{Rp} / \mathrm{Ha})$ & 0,623 & 226 & 0,534 & Non-significant \\
\hline Pesticide cost $(\mathrm{Rp} / \mathrm{Ha})$ & 0,879 & 226 & 0,380 & Non-significant \\
\hline Labor cost $(\mathrm{Rp} / \mathrm{Ha})$ & $-0,749$ & 226 & 0,455 & Non-significant \\
\hline Fixed cost $(\mathrm{Rp} / \mathrm{Ha})$ & 0,812 & 226 & 0,417 & Non-significant \\
\hline Depreciation $(\mathrm{Rp} / \mathrm{Ha})$ & 0,647 & 226 & 0,518 & Non-significant \\
\hline Profit (Rp/Ha) & 1,340 & 226 & 0,181 & Non-significant \\
\hline R-C Ratio & 0,807 & 226 & 0,420 & Non-significant \\
\hline
\end{tabular}

Table 2. Difference Test Results for Production Factors, Revenues and R/ C between

Farmers Returning Straw and Not Returning Straw

There was no significant difference between the average income of rice farmers who returned straw and rice farmers who did not return straw due to two things, first the respondents who returned rice straw to the rice field entirely without composting treatment so that the yield was not optimal, as stated by Sugito et al., (1995) organic matter in addition to controlling erosion and increasing growth can also increase crop production or yield, both through covering and absorption. Organic farming uses small amounts of seeds, organic fertilizers, and organic pesticides. Organic farming makes farmers become more independent because they can make their own production inputs from organic materials around them such as livestock manure and agricultural waste that can be used as fertilizer. The use of production facilities provided by them can reduce production costs so that farmers can increase income.

Returning straw to the paddy field without composting treatment can be done through the natural decomposition stage by chopping the straws immediately after, then spread the straws to the rice field area and leave the rice field irrigated for two months. In this study, respondents only left it without irrigation and waited until the land was processed (less than two months). As stated by PTT Balitpa Team (2001), before straw is used as organic fertilizer in rice plants can be reached by means of direct utilization if the distance between harvests in the previous season with the following season is at least a period of two months, with the method is when harvesting straw is directly distributed to the plot of rice fields and then put in water until it is flooded, the straw will be decomposed within a period of two months. If the use of straw is done less than two months, it will be able to inhibit the growth of rice plants.

Second, it can be seen from the results of research that the percentage of straw returns by respondents is between $5 \%$ and $85 \%$, with an average of only $50 \%$, this figure is still too small, and so it has not affected the increase in soil fertility and yield productivity. This is in line with the results of research conducted by Arafah, et al., (2001) that the difference in the percentage of straw given will affect the yield of dry grain harvest obtained. The highest yield was obtained on $100 \%$ return of straw and the lowest yield was obtained without returning straw.

Table 2, shows that all production inputs are not significant, meaning that there is no significant difference between the amount of production input of the respondent farmers who return straw with those who do not. The absence of these differences made it possible for the respondent farmers not to absorb and apply all information regarding the usefulness of returning straw to the rice fields provided by the Field Agricultural Extension (PPL). This is different from the results of different tests for production; the results are significant, meaning that there is a significant difference between the productions of farmers who reuse straw to those who do not. The level of production will affect the income level of the respondent farmers. But the income level is not significant. This is because the fixed costs of land rent and 
depreciation of alsintan are higher for farmers who return straw than those who do not return. The two high costs are made possible by differences in the class of land rented by farmers. In general, the size of the land rent is influenced by several factors including: class of land type of land, type of plant cultivated, fertility and payment system. The higher the land class, the level of fertility (proxied from land productivity), and the economic value of the cultivated plants, the higher the value of land rent will be. The rent value of irrigated rice fields is higher than both rainfed and dry land. In the case of a payment system, if it is carried out before processing the land the rental value is relatively cheaper compared to the payment after planting. Furthermore, if the land can be directly cultivated, the rent value is relatively higher compared to the tenant having to wait to be able to cultivate the leased land. The longer waiting to be able to work on the land concerned, the smaller the rent value (Nasution, 1989). When viewed from technical efficiency, Handoko et al (2018) concluded that level of technical efficiency achieved by rice farmers who return straw to rice fields is $93 \%$ while in rice farming farmers who do not return straw to rice fields are $95 \%$, which means that both the farming system has been technically efficient.

\subsection{Determination Factors for Farmers to Recycle Their Straw}

One of the problems in increasing agricultural production is the low level of adoption of agricultural innovations. Soekartawi (2005) states that several important things in influencing the adoption of innovation include; age, education, courage to take risks, patterns of relationships, attitudes toward change, motivation to work, aspirations, fatalism, certain belief systems, characteristics of psychology. Mardikanto (1993) states that the speed of adoption is influenced by many factors, including; (a) the nature of its own innovation, (b) the nature of the target, (c) the way of making decisions, (d) the communication channels used and (e) the state of the instructor. The results of the study by Kustiari et al (2010) obtained factors and constraints on the adoption of innovative processing of food and food commodities, among others; assistance in the use of technology, and farmers are not used to dealing with banks.

The decision of rice farmers to restore straw or not is strongly influenced by various factors, both internal and external. In this study four internal factors have been identified, namely: Age, length of education, size of farming land and farm income, and 3 external factors, namely: economic environment, social environment and nature of innovation.

\subsubsection{Overall and Partial Testing of Logistic Regression Models}

From the Omnibus test output presented in Table 3, the sig model value $=0.083$, which means less than 0.1 . This means that with a confidence level of $90 \%$, there is at least one independent variable $\mathrm{X}$ which affects the non-independent variable Y. So, it can be concluded that the model can be used for further analysis.

\begin{tabular}{|l|c|c|c|c|}
\hline & & Chi-square & Df & Sig. \\
\hline Step 1 & Step & 12.582 & 7 & .083 \\
\cline { 2 - 5 } & Block & 12.582 & 7 & .083 \\
\cline { 2 - 5 } & Model & 12.582 & 7 & .083 \\
\hline \multicolumn{4}{|c|}{ Table 3: Omnibus Tests of Model Results } \\
Partial Test Results in Table 4 Below
\end{tabular}

\begin{tabular}{|c|c|c|c|c|c|c|c|}
\hline Var. & B & S.E. & Wald & df & Sig. & Exp(B) & Keputusan \\
\hline$X_{1}$ & -.018 & .012 & 2.278 & 1 & .131 & .982 & accept $H_{0}$ \\
\hline$X_{2}$ & -.006 & .045 & .018 & 1 & .893 & .994 & accept $H_{0}$ \\
\hline$X_{3}$ & -.507 & .364 & 1.937 & 1 & .164 & .602 & accept $H_{0}$ \\
\hline$X_{4}$ & .024 & .014 & 3.060 & 1 & .080 & 1.024 & refuse $H_{0}{ }^{*}$ \\
\hline$X_{5}$ & -.019 & .153 & .015 & 1 & .903 & .981 & accept $H_{0}$ \\
\hline$X_{6}$ & -.107 & .229 & .220 & 1 & .639 & .898 & accept $H_{0}$ \\
\hline$X_{7}$ & .090 & .053 & 2.853 & 1 & .091 & 1.094 & refuse $H_{0}{ }^{*}$ \\
\hline \multicolumn{7}{|c|}{}
\end{tabular}

Farmers to Return Straw to Rice Fields

Note: *Significant at Real Level 10\%

From Table 4, it can be concluded that there are two factors that significantly influence the decision of rice farmers to return straw or not, namely the level of income $\left(\mathrm{X}_{4}\right)$, and the nature of innovation $\left(\mathrm{X}_{7}\right)$. This conclusion is consistent with what was stated by Ramli (2012) that socioeconomic factors that influence farmers' adoption of technological innovation are (1) relatively low farmer income levels, (2) less comprehensive technological innovation creation process, (3) less technological innovation dissemination process effective, and (4) farmers still face various problems, both internal and external. Adoption in the extension process can essentially be interpreted as a process of other behavioural changes in the form of knowledge (cognitive), attitude (affective), and skills (psychomotoric) in a person after receiving "innovation" delivered by the instructor by the target community. Acceptance here means not just "know", but until it can truly implement or apply it correctly and live it in life in its farming efforts. Acceptance of these innovations can usually be observed directly or indirectly by others, as a reflection of changes in attitudes, knowledge and/or skills 
(Mardikanto 1996). Farmers' perception of a technological innovation is the process of organizing and interpreting the stimulus received by individual farmers, so that technological innovation is meaningful and useful and is an integrated activity in the individual before deciding to behave. The form of decision to behave is an individual's action to apply technological innovations that have been believed and proven.

According to Puspadi (2002), changes in farmers 'attitudes caused changes in farmers' needs. Current farmers' needs are a reasonable level of income and the availability of fresh money as an instrument to actualize themselves, develop themselves and defend themselves. In addition to psychological factors that determine attitudes, social communication is also the most dominant determinant in determining a farmer's attitude towards agricultural technology innovation. As explained above, a new technological innovation received by individual farmers through a process of perception. The formation of a person's attitude according to Mar'at (1984) is influenced by internal factors (physiological and psychological) and external factors (experience, situation, norms, obstacles and encouragement).

The fact that farmers' attitudes toward technological innovation are influenced by individual internal factors (individual personality characteristics) and internal factors (factors outside the individual). However, the more dominant influence of farmers' attitudes and decisions on an innovation are external factors. External factors include norms, habits, social communication, social interaction, and individual social learning in social systems. The social learning process that is often carried out by farmers in capturing information on new technological innovations is observational learning. According to Bandura Social Learning Theory (1977), the influence of modeling results in learning through informatic functions. Individuals can achieve symbolic images of activities that function as guides for the implementation of appropriate actions. Farmers' attitude towards technological innovation is also influenced by the condition of the natural environment (agro-ecosystem and agro-climate), this is one factor that might be called Mar'at (1984) as an "obstacle" which is one of the external variables that determine attitudes, especially suitability the technology is to the conditionecosystem and local agro-climate.

The nature of innovation, the nature of innovation will also determine the speed of adoption of innovation. As stated by Hanafi (1987), there are five types of innovations that affect the speed of adoption of an innovation, namely: 1) relative advantage is the level that shows a new idea is considered a better than the ideas that existed before. The level of relative profit is often expressed with or in the form of economic benefits, 2) compatibility (the relationship of innovation to the client's situation) is the extent to which an innovation is considered consistent with existing values, experience and the needs of the recipient. Ideas that are incompatible with prominent social system characteristics will not be adopted as quickly as compatible ideas, 3) complexity (complexity of innovation) is the degree to which an innovation is considered relatively difficult to understand and use, 4) triability (an innovation can be tried) is a level where an innovation can be tried on a small scale, 5) observability (can be observed an innovation) is the level at which the results of an innovation can be seen by others.

According to Maman, et al, (2016) the description of the characteristics of pantura farmers, especially from a social and economic perspective includes age, farming experience, education, and general conditions of farm families. This becomes important to provide a general description of social characteristics which can later contribute to psychographic analysis. So that the level of adaptation and social potential for the development of innovations supporting agricultural development both from within and from outside can be detected. Furthermore, as a basis for determining the area if in the future intervention or engineering will be carried out in the framework of agricultural development. The age characteristics of farmers in West Java dominated by old farmers means that generically old farmers have low adoption rates that are closely related to their farming experience. The level of education of farmers in the West Java region, especially pantura, is relatively low which affects the level of technology adoption and the absorption of information, especially those coming from external sources. Nevertheless, most farmers have received non-formal education through field schools and counseling conducted by the local government.

Green revolution technology raises various problems such as leveling off, low profitability of farmers due to high levels of input costs, environmental problems, and health as well as nutrient and pest imbalances (Minami, 1997). These problems have encouraged thinking to implement low-input sustainable agriculture (LEISA) or organic farming (organic farming). In organic farming, there is the addition of organic matter as an environmental improvement measure to grow plants to improve and optimize the benefits of fertilizer so that its efficiency increases.

The use or management of straw can be carried out by transporting straw to the outside of the field, burning straw on the ground, immersing straw, or by composting straw. The decline in rice yields on rice fields that are continuously cultivated often occurs especially if the straw is transported. The transport of straw at harvest reduces soil fertility because most organic matter and soil nutrients are transported to other places so that in the long run soil fertility will decrease. Returning rice straw or providing organic matter is expected to improve nutrient balance so that the preservation of rice field fertility can be maintained.

It is expected that there will be no more straw that is burned or transported out of the field due to reasons to eliminate difficulties during tillage, control pests and diseases, save energy or for animal feed and for other purposes. Addition of organic matter can reduce the use of inorganic fertilizers. Organic matter is needed to maintain soil fertility by maintaining and improving the function of microorganisms in the soil to increase the availability of nutrients in the soil also increase the effectiveness of fertilization. Therefore, the management of organic material in rice fields combined with inorganic fertilizer is needed to increase rice productivity. The addition of organic matter can increase fertilizing efficiency so that the growth and yield of rice can increase (Amrah, 2008). 


\section{Conclusion and Suggestion}

\subsection{Conclusion}

- The level of production, income, and R/ C ratio of farmers who return straw tends to be higher than not returning, even though the difference is not significant.

- Factors that influence the decision of farmers to return straw to rice fields, namely the level of income and the nature of innovation.

\subsection{Suggestion}

- The level of farmers' understanding of the usefulness of straw as an inorganic fertilizer substitute and soil fertility restorer must be increase; this can be done by strengthening the farmer group institutions and synergizing with the Agricultural Field Extension (PPL).

- It is expected that the government through the local Agriculture Service can better facilitate and encourage programs that focus on local wisdom and the use of rice straw waste to be returned to the rice fields as organic fertilizer as a reduction in the use of excess inorganic fertilizer, thereby reducing production costs and further increasing farmers' income.

\section{Acknowledgments}

The research team would like to thank the Rector of Padjadjaran University who has provided funding for our research through the Academic Leadership Program scheme (ALG) 2018, under the title: Restructuring the Model of Rice Agribusiness Institution in West Java, Indonesia.

\section{References}

i. Agus, F., dan D. Setyorini. 2007. Pelestarian Lahan Sawah. Balai Penelitian Tanah. Bogor

ii. Amrah, M. L. 2008. Pengaruh manajemen jerami terhadap pertumbuhan dan produksi padi sawah (Oryza sativa L.). Skripsi. Fakultas Pertanian Institut Pertanian Bogor. Bogor.

iii. Arafah dan M. Sirappa. 2002. Kajian Penggunaan Jerami dan Pupuk N, P dan K pada Lahan Sawah Irigasi. Ilmu Tanah dan Lingkungan. BPTP Sulawesi Selatan

iv. Asogwa, Joseph, and Simon. 2011. Economic Efficiency of Nigerian Small Scale Farmers.J Economics,2(2) : 89-98 (2011).

v. BPS Kabupaten Subang. 2016-2017. Subang dalam angka. BPS Subang.

vi. BPS Jawa Barat. 2016. Perbandingan Luas Panen Padi (Ha) Menurut Jenis di Jawa Barat Tahun 2013 - 2015.

vii. Dinas Pertanian Jawa Barat. 2007. Rekomendasi Penggunaan Pupuk Propinsi Jawa Barat.

viii. Direktorat Jenderal Prasarana dan Sarana Pertanian. 2014. Pedoman Peningkatan Kinerja Komisi Pengawasan Pupuk dan Pestisida (KPPP) serta Pemberdayaan PPNSTahun 2014. Kementerian Pertanian, Jakarta. 1-2

ix. Doll, P., and F. Orazem. 1984. Production Economics: Theory with Application. Wiley. New York (US).

x. Geli Bulu, Y., 2010. Kajian Pengaruh Modal Sosial dan Keterdedahan Informasi Inovasi Terhadap Tingkat Adopsi Inovasi Jagung di Lahan Sawah dan Lahan Kering di Kabupaten Lombok Timur. Disertasi. Universitas Gadjah Mada.

xi. Hanafi, Abdillah. 1987. Memasyarakatkan Ide-Ide Baru. Usaha Nasional. Surabaya.

xii. Handoko, Lies Sulistyowati, Elly Rasmikayati. 2018. Economic efficiency analysis of rice farming that returns straw compared to those that do not return straw to rice fields in Subang Regency, West Java-Indonesia. International Journal of Innovative research and Development. Vol. 7 Issue 8. August 2018.

xiii. Herman, M. Parulian Hutagaol, Surjono H. Sutjahjo, Aunu Rauf dan D. S. Priyarsono. 2006. Analisis Faktor-Faktor yang Mempengaruhi Adopsi Teknologi Pengendalian Hama Penggerek Buah Kakao. Studi Kasus di Sulawesi Barat. Pelita Perkebunan 22.

xiv. Kustiari, R., H.P Salim., S. Pasaribu, B. Sayaka, dan E. Surya. 2010. Akselerasi Sistem Inovasi Inovasi Pengolahan Hasil dan Alsintan Dalam Rangka Mendukung Ketahanan Pangan. Laporan APBN Pusat Analisis Sosial Ekonomi dan Kebijakan Pertanian.

xv. Isro. 2009 through: http;/ / isroi.com/ 2009/ 05/ 13/ Hasil-Analisa-kompos-jerami-dan-nilai-haranya.html

xvi. Launio, Cheryll C., Constancio A. Asis, Jr., Rowena G. Manalili, Evelyn F. Javier. 2013. Economic Analysis of Rice Straw Management Alternatives and Understanding Farmers' Choices. WorldFish (ICLARM) - Economy and Environment Program for Southeast Asia (EEPSEA), SEARCA bldg., College, Los Baños, Laguna 4031 Philippines

xvii. Maman H. Karmana, Lies Sulistyowati, Engkus K. Wikarta, Trisna Insan Noor, Nono Carsono, Eti Suminartika, dan Sri Fatimah. 2016. Akselerasi Pembangunan Pertanian Melalui Restrukturisasi Kelembagaan Kerjasama Petani Padi di Jawa Barat. Bandung. Laporan Akhir. Hibah Academic Leaderships Grant (ALG). Fakultas Pertanian. Universitas Padjadjaran

xviii. Mar'at. 1984. Sikap Manusia, Perubahan serta Pengukurannya. Jakarta. Ghalia Indonesia.

xix. Mardikanto, Totok. 1993. Penyuluhan Pembangunan Pertanian. Surakarta. Sebelas Maret University Press.

xx. Mardikanto, Totok. 1996. Penyuluh Pembangunan Kehutanan. Jakarta. Pusat Penyuluhan Kehutanan Departemen Kehutanan RI bekerjasama dengan Fakultas Pertanian Universitas Sebelas Maret (UNS).

xxi. Minami, N.O. 1997. Low External Input for Sustainable Agriculture. Tokyo. Japan. Dalam Appropriate Use of Inputs for Sustainable Agriculture. Proceeding Seminar APO. 27 Augst - 6 Sept 1996. 
xxii. Najmudin, Asep, Lies Sulistyowati, Maman, H.K, Yosini, D. 2017. The Pattern of Food Consumption Expenditure and Performance of Household Food Security (Case at Rural and Urban in West Java Province). International Journal of Innovative research and Development. Vol.6 Issue 9. September 2017.

xxiii. Nasution, Z. 1989. Prinsip Prinsip Komunikasi Untuk Penyuluhan. Lembaga Penerbit FE UI. Jakarta Nugroho, N. 2011. Perbaiki Kesuburan Tanah Melalui Pengembalian Jerami Padi. Balai Pengkajian Teknologi Pertanian Jambi.

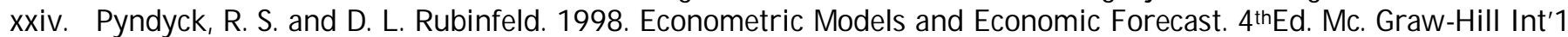
Edition.

xxv. Puspadi, K. 2002. Rekonstruksi Sistem Penyuluhan Pertanian. Disertasi. Program Pasca Sarjana Institut Pertanian Bogor.

xxvi. Rogers. E.M.1983. Diffusion of Inovation. 3ed. New York. Collier Macmillan Publishing Co.Inc.

xxvii. Rosinta Br. Sitepu. 2013. Pemanfaatan Jerami Padi sebagai Pupuk Organik untuk Meningkatkan pertumbuhan dan produksi padi. Departemen Ilmu Tanah dan Sumber Daya Lahan Fakultas Pertanian IPB

xxviii. Saptana. 2012. Konsep efesiensi Usahatani Pangan dan Implikasinya bagi Peningkatan Produktivitas. Pusat Sosial dan Kebijakan Petanian Bogor.

xxix. Safitri. 2010. Melalui: https:// safitrianggrainidewi.wordpress.com/ .../ makalah-dampak-penggunaan-pupukkimia-berlebihan.html (30 Agustus 2014)

xxx. Soekartawi. 1988. Prinsip Dasar Komunikasi Pertanian. Universitas Indonesia. Jakarta

xxxi. Soekartawi. 2002. Analisis Usahatani. Jakarta. Penerbit Universitas Indonesia (UI-Press).

xxxii. Suharyanto, Jangkung H. Mulyo, Dwidjono H. Darwanto dan Sri Widodo. 2015. Analisis Produksi dan Efisiensi Pengelolaan Tanaman Terpadu Padi Sawah di Provinsi Bali. Jurnal Pengkajian dan Pengembangan Teknologi Pertanian Tanaman Pangan VoL. 34 No. 22015

xxxiii. Sugito, Y., Yulia N, dan Ellis N. 1995. Sistem Pertanian Organik. Fakultas Pertanian Universitas Brawijaya. Malang.

xxxiv. Sugiyono. 2012. Metode Penelitian. Bandung. Penerbit Alfabeta

xxxv. Sumarno dan Unang G. Kartasasmita. 2012. Kesiapan Petani Menggunakan Pupuk Organik Padi Sawah. Pusat Penelitian dan Pengembangan Tanaman Pangan. Bogor.

xxxvi. Sumaryanto, S. Friyatno, dan B. Irawan. 2001. Konversi Lahan Sawah ke Penggunaan Nonpertanian dan Dampak Negatifnya. Pusat Penelitian Sosial Ekonomi Pertanian. Bogor.

xxxvii. Supriyati. 2010. Dinamika Ekonomi Ketenagakerjaan Pertanian: Permasalahan dan Kebijakan Strategis Pengembangan. Puslitbang Sosial Ekonomi Pertanian. Bogor. Volume 8 No. 1 Maret 2010.

xxxviii. Suriadikarta dan Simanungkalit, 2006. Pupuk Organik dan Pupuk Strawati. Balai Besar Penelitian dan Pengembangan Sumberdaya Lahan Pertanian. Bogor.

xxxix. Tiedemann T and Uwe L. 2012. Production risk and tecnical efficiency in organic and conventional agriculture. the case of arable farms in Germany. JAE.

xl. Tim PTT Balitpa, 2001. Penggunaan Kompos Jerami Menunjang Program Pengelolaan Tanaman Terpadu. Balitpa Sukamandi. 